\title{
Salt marsh peat reefs as protection for postlarval lobsters Homarus americanus from fish and crab predators: comparisons with other substrates
}

\author{
Diana E. Barshaw ${ }^{1, *}$, Kenneth W. Able ${ }^{1}$, Kenneth L. Heck, $\mathrm{Jr}^{2}$ \\ 'Marine Field Station, Institute of Marine and Coastal Sciences, Rutgers University, 800 Great Bay Boulevard, Tuckerton, New Jersey 08087, USA \\ ${ }^{2}$ Marine Environmental Science Consortium, University of South Alabama, Dauphin Island, Alabama 36528, USA
}

\begin{abstract}
This evaluation of habitat quality for early juvenile lobsters Homarus americanus was based on 2 measures: time to settle and degree of survival. Predation upon settling postlarval lobsters by fish (cunners Tautogolabrus adspersus) and crabs (green crabs Carcinus maenas) was compared in 3 different substrates (cobble, peat and sand). Cobble provided lobsters with significantly more protection from fish than either peat or sand, and peat provided significantly more protection than sand. Cobble also provided lobsters with significantly more protection from crabs than peat or sand. However, rates of predation between peat and sand were not consistent with crabs as the predator. The postlarvae quickly settled into cobble and peat, but delayed settling into sand, suggesting that cobble and peat were preferred habitats, which is generally consistent with the predation levels observed.
\end{abstract}

KEY WORDS: Lobster - Homarus americanus - Salt marsh Predation - Habitat

The role of various substrates as refuges has been examined for early juvenile lobsters. Of the substrates tested, rock consistently provided the most protection, with eelgrass and mud providing better protection than sand (Roach 1983, Barshaw \& Lavalli 1988, Wahle \& Steneck 1992).

However, Able et al. (1988) found high densities (range 0 to 5.7 ind. $\mathrm{m}^{-2}$, mean 2.5 ) of early juvenile lobsters Homarus americanus (<40 mm carapace length, $\mathrm{CL}$ ) in a previously untested and undescribed habitat, salt marsh 'peat reefs' on Cape Cod, Massachusetts, USA. These consist of large (between 5 and $7 \mathrm{~m}$ long), irregular blocks of salt marsh peat and living marsh plants that break off from the marsh surface and fall into adjacent marsh creek channels. Green crabs

\footnotetext{
- Present address: Center for Maritime Studies, University of Haifa, Haifa 31905, Israel
}

Carcinus maenas and the fish, cunners Tautogolabrus adspersus are some of the most abundant potential lobster predators found in this habitat (Able et al. 1988).

The purpose of this study was to evaluate the quality of peat reef as juvenile lobster habitat in comparison with 2 other substrates: cobble and sand, previously determined to be good and poor habitats, respectively (Botero \& Atema 1982, Lavalli \& Barshaw 1986, Barshaw \& Lavalli 1988). Comparisons were based on 2 measures of habitat quality: time to settling and survival against 2 different types of predators, green crabs and cunners.

Materials and methods. Thirty-two replicate tanks $10.6 \mathrm{~m}$ wide, $0.8 \mathrm{~m}$ long, $0.6 \mathrm{~m}$ deep) were supplied with flowing, ambient, unfiltered seawater. Tanks contained either sand $(10 \mathrm{~cm}$ deep), cobble $(0.1$ to $20 \mathrm{~cm}$ diameter, $12 \mathrm{~cm}$ deep) over a sand base, or peat reef ( 5 to $30 \mathrm{~cm}$ deep) also over a sand base. The cobble was collected from subtidal areas in Woods Hole, Massachusetts, while the peat reef was collected near the study area at Rutgers University Marine Field Station, Tuckerton, New Jersey, USA. For the first series of experiments (Run 1) 14 tanks were designated as predator-free controls. The remaining 18 were divided evenly between the 3 substrates and 2 predator species (Table 1).

After a $1 \mathrm{wk}$ acclimation period for the substrates, 10 $\left(=20.8 \mathrm{~m}^{-2}\right)$ late (reared) Stage IV lobsters were placed into each of the tanks in Run 1. Lobsters were allowed $2 \mathrm{~d}$ to settle and build burrows, and were fed daily with frozen brine shrimp. After $2 \mathrm{~d}$ feeding was terminated and predators introduced. Either 3 cunners $\left(=6.2 \mathrm{~m}^{-2}\right.$, 55 to $120 \mathrm{~mm}$ total length, TL) or 5 green crabs $(=10.4$ $\mathrm{m}^{-2}, 35$ to $65 \mathrm{~mm}$ carapace width, CW) were placed in each experimental tank. Predators were left for $4 \mathrm{~d}$ 
Table 1 Homarus americanus preyed upon by Carcinus maenas and Tautogolabrus adspersus. Number of replicate treatments in each substrate in each run for each predator. In Runs 1 \& 2 the Iobsters were placed into the tanks $2 \mathrm{~d}$ before the predators. In Run 3 the predators were placed into the tanks 2 d before the lobsters

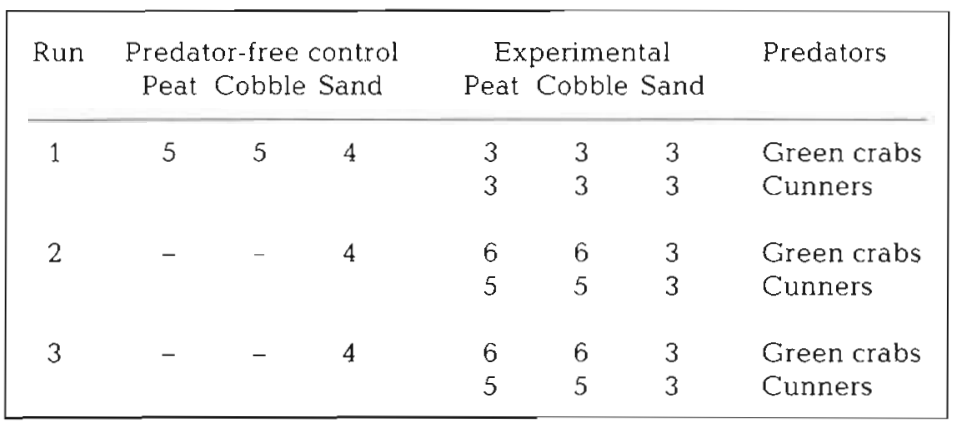

Survival: There were no significant differences between the number of lobsters surviving in the controls of different substrates, so these data from Run 1 were combined for subsequent analyses. There also was no significant difference between the number of lobsters surviving in the sand controls of the 3 runs.

With fish as predators, lobster survival was highest in cobble, intermediate in peat and zero in the sand (Table 2). With green crabs as the predators, there were no significant differences between lobster survival in cobble among the 3 runs and cobble always provided significantly better protection against after which time they were removed and the substrates sorted to determine the number of surviving lobsters. Censuses were taken on the number of lobsters still swimming in the water column, 4 times daily for the 6 d of each run.

Run 2 was similar, except we eliminated the peat and rock controls (Table 1). This was done because we found no significant differences between the controls of each substrate in Run 1 and no differences were found between controls of different substrates in similar previous experiments (Barshaw \& Lavalli 1988). Run 3 had the same arrangement of substrates and predators as in Run 2, but to test the effect of prior residence, predators were introduced into the tanks before the lobsters. Predators were given $2 \mathrm{~d}$ to acclimate, after which 10 lobsters were placed in each tank. Interactions between lobsters and predators were observed for $10 \mathrm{~min}$ after the lobsters were introduced. The lobsters remained in the tanks for $4 d$, after which substrates were sorted for surviving lobsters.

During these runs water temperature and salinity ranged from 22 to $28^{\circ} \mathrm{C}$ and 24 to $29 \%$ respectively.

The census data were analyzed with a 2-way ANOVA testing for the effects of time since lobster introduction and substrate type on the number of lobsters remaining in the water column. The survival data were analyzed for differences between runs and between substrate types using contingency tables analyzed with Chi-square tests.

Results. Time to settling: There were no significant differences in the time to settling between Run 1 and Run 2 (Students t-test, $p>0.1$ ) so these data were combined. A significantly greater number of lobsters remained swimming over sand substrate than over either peat or cobble substrates (Fig. 1, 2-way ANOVA, $p<0.001$; Student-Newman-Keuls test, $p<0.05$ ). There was no significant difference between the number of lobsters swimming over peat versus cobble.

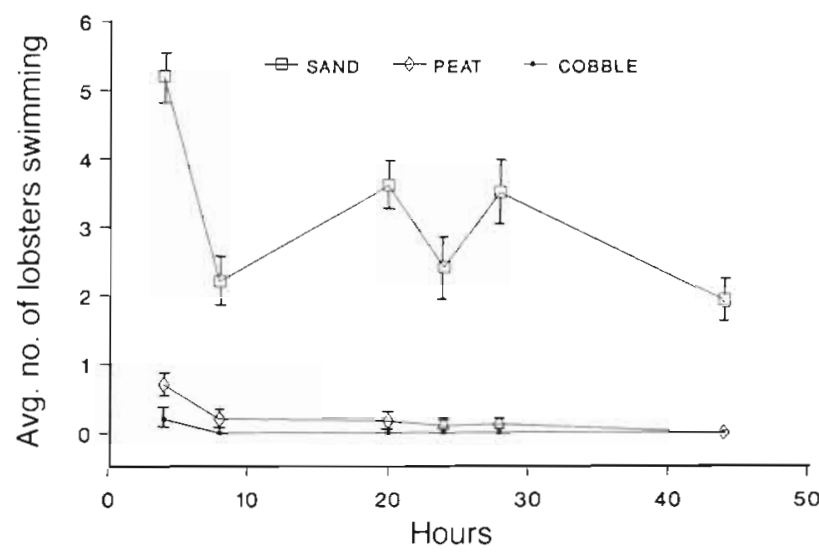

Fig. 1. Homarus americanus. Average number of juvenile lobsters ( $\mathrm{n}=10$ per tank) swimming over sand, peat reef and cobble substrates during the first $44 \mathrm{~h}$ of the experiment (before predators were introduced). Sand vs Peat and Cobble, $p<0.001$. Bars indicate standard error

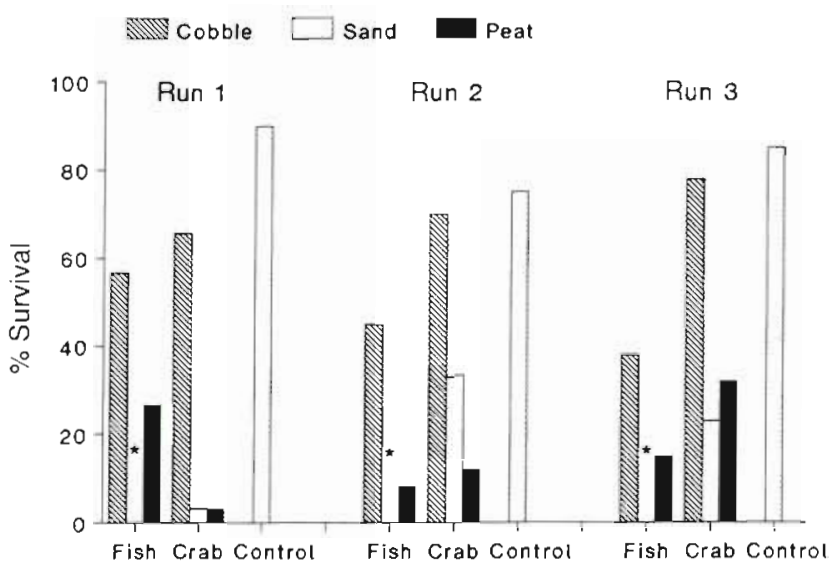

Fig. 2. Homarus americanus. Percent of lobsters surviving predation by cunners Tautogolabrus adspersus, and green crabs Carcinus maenas, in 3 different substrates. In Run 3 the predators were introduced before the lobsters. "Survival of lobsters was zero in the sand substrates with fish predators 
Table 2. Differences in lobster Homarus americanus survival between the 4 treatments (C: predator-free controls; CO: cobble; P: peat; S: sand) and the 2 types of predators (cunners Tautogolabrus adspersus, and green crabs Carcinus maenas) based on Chi-square tests

\begin{tabular}{|c|c|c|c|c|}
\hline & Run 1 & Run 2 & Run 3 & Between runs \\
\hline $\begin{array}{c}\text { Cunners } \\
\mathrm{p}<\end{array}$ & $\begin{array}{c}\mathrm{C}>\mathrm{CO}>\mathrm{P}>\mathrm{S} \\
0.01 \quad 0.01 \quad 0.001\end{array}$ & $\begin{array}{c}\mathrm{C}>\mathrm{CO}>\mathrm{P}>\mathrm{S} \\
0.05 \quad 0.0010 .01\end{array}$ & $\begin{array}{c}\mathrm{C}>\mathrm{CO}>\mathrm{P}>\mathrm{S} \\
0.010 .050 .01\end{array}$ & No differences \\
\hline $\begin{array}{l}\text { Green crabs } \\
\quad p<:\end{array}$ & $\begin{array}{c}\mathrm{C}>\mathrm{CO}>\mathrm{P}, \mathrm{S} \\
0.050 .001\end{array}$ & $\begin{array}{c}\text { C. CO > S > P } \\
0.0010 .05\end{array}$ & $\begin{array}{c}\mathrm{C}, \mathrm{CO}>\mathrm{P}, \mathrm{S} \\
0.001\end{array}$ & $\begin{array}{c}\mathrm{P}(\text { Run } 3)>\mathrm{P}(\text { Runs } 1 \& 2) \\
0.05 \\
\mathrm{~S} \text { (Runs } 2 \& 3)>\mathrm{S}(\text { Run } 1) \\
0.05\end{array}$ \\
\hline
\end{tabular}

the crabs than either sand or peat. There were differences between runs when comparing sand and peat (Table 2). There were no significant differences between lobster survival in the peat or sand substrate in either Run 1 or Run 3. However, in Run 2, a greater number of lobsters survived in the sand than in the peat (Fig. 2, Table 2).

Discussion. These experiments were not designed to provide data on the absolute predation rate that lobsters experience in the field. Rather they were designed to provide relative comparisons of habitat quality and predator differences. Our results for the sand and cobble substrates (Fig. 1, Table 2) are consistent with previous experiments that also show that early juvenile lobsters delay settling into sand, while quickly settling into cobble (Botero \& Atema 1982, Barshaw \& Bryant-Rich 1988, Barshaw \& Lavalli 1988). Although there was a tendency toward quicker settling into cobble (i.e. almost immediate settlement), peat is similar by this measurement of habitat preference (Fig. 1).

Lobster survival varied with type of predator and this presumably reflects differences in predator behavior in different habitats (Fig. 2). When cunners were the predators, the survival data mirrored the ranking for the settling data. When green crabs were used as predators, cobble provided the best protection. In previous experiments with mud crabs Neopanope sayi as predators, using the same size cobble, juvenile lobsters of the same stage suffered high mortalities (Lavalli \& Barshaw 1986, Barshaw \& Lavalli 1988). However, the green crabs used in these trials were larger (35 to $65 \mathrm{~mm} \mathrm{CW}$ ) than the mud crabs ( 11 to $25 \mathrm{~mm} \mathrm{CW}$ ) used in the previous experiments, and thus may not have been able to enter small burrows or interstices between the cobble that could be occupied by a small juvenile lobster. Roach (1983) also found that large crabs Cancer irroratus were unable to prey upon early juvenile lobsters occupying cobble habitats.

Peat did not provide better protection relative to sand when green crabs were used as predators and, in
Run 2, more lobsters survived in the sand than in the peat substrates. The ability of green crabs to burrow readily into peat was evident in our field collection for individuals of this species. Also, during the experiments, crabs were observed making tunnels and ripping up the peat. Thus, green crabs may be capable of digging juvenile lobsters out of their burrows. Despite these laboratory results, juvenile lobsters do survive in peat reefs (Able et al. 1988). It is interesting to note that at the site of this earlier study, cobble habitat was lacking (pers. obs.).

An unexpected result from this experiment was that the occurrence of predators in the substrates prior to introduction of lobsters (Run 3) did not decrease survival. Intuitively it would seem that while the lobsters were building their burrows they would be especially vulnerable; however, our results do not support this hypothesis.

The observation that time to settle consistently ranks substrates in the same order and that, at least with fish as predators, those substrates in which lobsters settle fastest are the same in which they have the highest survival rate, suggests that these tests are useful indicators of habitat quality.

Our study combined with the Able et al. (1988) field survey emphasizes that early juvenile lobsters are flexible in their choice of habitat and that they are capable of burrowing and surviving in rock and peat substrates.

Acknowledgements. We thank our friends and colleagues at the Rutgers University Marine Field Station, all of whom helped at some point during the labor intensive portions of the experiment. Special thanks go to Jeanette Bowers, Byungja Marciante and Elizabeth Semple who helped collect the substrates, take censuses and sort for the juvenile lobsters. Mike Syslo and Kevin Johnson from the Massachusetts State Lobster Hatchery, Martha's Vineyard, and Andrew Paterson from the Cutler Marine Hatchery, Cutler, Maine, provided Stage IV lobsters. Financial support was provided by the National Park Service, Cooperative Research Unit, and the Institute of Marine and Coastal Sciences (IMCS), Rutgers University. This is IMCS Contribution No. 94-01. 


\section{LITERATURE CITED}

Able, K. W., Heck, K. L. Jr, Fahay, M. P., Roman, C. T. (1988). Use of salt-marsh peat reefs by small juvenile lobsters on Cape Cod, Massachusetts. Estuaries 11: 83-86

Barshaw, D. E., Bryant-Rich, D. R. (1988). A long-term study on the behavior and survival of early juvenile American lobsters, Homanus americanus, in three naturalistic substrates: eelgrass, mud, and rocks. Fish. Bull. U.S. 86: 789-796

Barshaw, D. E., Lavalli, K. L. (1988). A comparison of predation on post-larval American lobsters by cunners and mud crabs in three different substrates: eelgrass, mud and rocks. Mar. Ecol. Prog. Ser. 48: 119-123

Botero, L., Atema, J. (1982). Settlement and substrate selection during larval settling in the lobster, Homarus ameri-

This note was submitted to the editor canus. J. crust. Biol. 2: 59-69

Lavalli, K. L., Barshaw, D. E. (1986). Burrows protect postlarval American lobsters, Homarus americanus, from predation by the non-burrowing cunner, Tautogolabrus adspersus, but not from the burrowing mud crab, Neopanope texani. Mar. Ecol. Prog. Ser. 32: 13-16

Roach, G. S. (1983). Survivorship, growth, and behavior of juvenile lobsters, Homarus americanus, Milne-Edward in controlled environment in nature. Rept. No. 83-02, Manuscript and Technical Report Series, Department of Fisheries, Nova Scotia, Canada

Wahle, R. A., Steneck, R. S. (1992). Habitat restrictions in early benthic life: experiments on habitat selection and in situ predation with the American lobster. J. exp. mar. Biol. Ecol. 157: 91-114

Manuscript first received: September 3, 1993

Revised version accepted: December 23, 1993 